\title{
Vietnamese University EFL Teachers' Reported and Classroom Practices in Teaching Listening
}

\author{
Ly Thanh Danh ${ }^{1}$, Nguyen Hai Quan ${ }^{2}$ \\ ${ }^{1}$ Bachelor, School of Foreign Languages, Can Tho University, Vietnam \\ ${ }^{2}$ Doctor, School of Foreign Languages, Can Tho University, Vietnam
}

\begin{abstract}
This study explored Vietnamese university EFL teachers' perceptions of the importance of listening skill and their reported and classroom practice in listening instruction. The exploration of the teachers' teaching practice was centered among three aspects including listening subject matter contents, listening lesson design, and the activities they employed for listening lessons. Six lecturers who taught listening skill to Englishmajored undergraduates at a university in Vietnam participated in the study. Data were collected via semistructured interviews and classroom observations. Findings from the study showed that the teachers had an intense awareness of listening skill as a crucial input source for language learning whereas the position of listening as a macro-language skill seemed to be downplayed. In both reported and classroom practices, vocabulary, topical knowledge, and listening strategies were found to occupy a central position as teaching content. In designing lessons, the teachers appeared to align more with the "comprehension" or "productoriented" approach which further bears a resemblance to the presentation, practice, and production (PPP) model with some updated features. The teachers were also found to share a common group of instructional activities in each of the three lesson stages. These findings provide important bases for future endeavors to further improve the effectiveness in teaching and learning the listening skill at the tertiary level.
\end{abstract}

Keywords - listening skill pedagogy, teachers' perceptions, reported and classroom practices, listening lesson structure, listening subject matter content knowledge

\section{INTRODUCTION}

Listening has been considered as "the key to knowing a language" (Wilson, 2016) since it has a profound impact on the acquisition of other language skills (Rost, 2001; Vandergrift, 2007). This important role of listening skill, however, is often either overlooked or undervalued in second language acquisition. Nunan (1997) argues that listening has been "treated as the Cinderella" among the four macro language skills of speaking, listening, reading, and writing. Wilson (2016) contends that listening "is probably the least understood, the least researched and historically, the least valued" (p.17). In general, limited attention to listening skill is evident from language teaching pedagogy and research, which in turn appears to result in two alarming realities. Firstly, research evidence has suggested that teachers in different contexts seem to be underprepared for teaching this particular skill. With insufficient knowledge and skills for effectively developing students' listening skill in a principled manner, teachers have a tendency to approach listening instruction from a comprehension approach (Field, 2008). In other words, they tend to focus on having students do the listening tasks in the materials, and the intended outcome of listening lessons is typically the achievement of successful comprehension (Field, 2008; Goh, 2008, 2010). This product-oriented approach, as such, places more focus upon the product of listening and every listening activity becomes a test of the listener's listening ability (Goh, 2008, Graham et al., 2014). As a result, although listening teaching still takes place in the classrooms, not much listening learning and improving will take place.

Secondly, with respect to learners' proficiency levels, listening has been identified to be one of the least successful among the four language skills (Graham, 2006). In various contexts, listening is among the skills that students find most challenging to master. A few studies conducted in the Vietnamese context focusing on learners' problems in listening show that listening is still considered to be the most challenging among the four macro skills for Vietnamese students (Duong \& Chau, 2019; Tran \& Duong, 2020). These studies further pointed out that one of the key reasons for this reality has been the underemphasis on the listening skill in the English learning process at most Vietnamese schools (Duong \& Chau, 2019; Nguyen \& Thai, 2018). In other 
DOI: $\underline{10.51386 / 25815946 / \mathrm{ijsms}-\mathrm{v} 4 \mathrm{i} 5 \mathrm{p} 102}$

words, the task of obtaining a clear picture of how teachers in different school levels perceive this skill and how they actually enact listening instruction is of crucial value but has been long overdue.

As a response to this dearth of understanding of the topic in the existing literature, the current study examines the teaching of the listening skill at the tertiary level in the Vietnamese context with a three-fold purpose. First, this study explores teachers' perceptions about the importance of the listening skill and their goals in listening instruction. Second, it inspects the teachers' reported and actual practices in teaching listening skill. The investigation into the teachers' practices emphasized the three important pedagogical aspects (1) what specific contents the teachers included in listening instruction, (2) how they structured their listening lessons and (3) what activities they employed for their listening lessons. In accordance with these aims, the study seeks to answer three following specific questions:

(1) What general perceptions do teachers hold about the importance of listening skill?

(2) As reported by the teachers, how is listening skill taught to their students?

(3) How is listening skill instruction actually enacted in the teachers' classroom context?

\section{LITERATURE REVIEW}

\section{A. Listening: Definition and its roles in language learning and teaching}

Listening has been defined as a highly complicated interactive process that listeners engage in (Buck, 2001; Holden, 2004; Vandergrift, 1999). In such a process, listeners need to tap into different aspects of expertise including language and topical background knowledge, cognitive and metacognitive skills to make sense of the messages conveyed. Rivers (1978) also views listening as both a creative skill and a complex process through which listeners grasp the sound falling on their ears, and take the raw material of words, word groupings, and the rise and fall of the voice, and from this material they create significance. Such a process could be highly challenging to listeners, especially to those at a low level since they have to engage with "processes and texts that are hidden from view" (Vandergrift \& Goh, 2018, p.126). As a whole, there seems to be a consensus among listening specialists that listening is a challenging cognitive process in which listeners make use of all linguistic and extra-linguistic resources at hand to decode the meaning of the listening texts.

In language learning, listening is seen as "the key to knowing a language" (Wilson, 2016, p. 17). Also, listening serves the role of input sources for the learning, processing, and mastering of other language skills such as speaking and writing. In other words, listening texts provide language learners with necessary language input (Rost, 1994) that they might extract, learn and apply in language production. Listening itself, however, is also an important macro-language skill that should be taught and learned in a principled and systematic manner. As Vandergrift and Goh (2018) maintain, although having students practice doing listening exercises is useful, it is simply not sufficient. Students need "guidance and scaffolding to understand and develop the processes of listening so that they can develop their listening comprehension explicitly and systematically, just as they do for their reading, writing and speaking development" (Vandergrift \& Goh, 2018, p. 124). In language teaching, as such, listening plays a dual role as both a means for input and an important learning target that teachers and learners need to pay sufficient attention to.

\section{B. Listening processes}

Understanding the listening processes could be seen as critical to the development of students' listening ability. This is because when listening, listeners rely on a number of different cognitive processing systems such as attention, perception, and memory that interactively work together to transform language and create meaning from what has been heard (Vandergrift \& Goh, 2018). The understanding of the comprehension processes, in turn, appears to rely mainly on the broad distinction between bottom-up and top-down processing (Vandergrift \& Goh, 2018). In its brief sense, the bottom-up process refers to learners' effort to understand a text by lexical segmentation or segmenting individual sounds, words, or phrases to decode the meaning (Field, 2008). In contrast, the top-down process happens when listeners draw on their prior knowledge about the topic and the listening context to assist their understanding of the listening text (Vandergrift \& Goh, 2018). Brown (2006) suggests that it is the act of "using our prior knowledge and experiences" through which "we know certain things about certain topics and situations and use that information to understand" (p. 2). Flowerdew and Miller 
DOI: $\underline{10.51386 / 25815946 / \mathrm{ijsms}-\mathrm{v} 4 \mathrm{i} 5 \mathrm{p} 102}$

(2005) further assume that in employing contextual knowledge to interpret utterances, listeners "use preestablished patterns of knowledge and discourse structures stored in memory" (p. 25). It means that the topdown listening process allows listeners to integrate their prior knowledge of the subject with what they hear during the listening process (Newton \& Nation, 2020) to enable them to make sense of what they hear.

In general, each of these two processes has an important role to play in listeners' success. In practice, however, these processes rarely operate independently from each other, but rather as parallel processes. For effective listening, it is suggested that listeners need to learn how to use both processes in an appropriate manner depending on the purpose and context in listening as well as specific characteristics of the listeners (Vandergrift $\&$ Goh, 2018). Flowerdew and Miller (2005), on the basis of Rumelhart's (1975) interactive model, suggest parallel processing, which is seen as a synthesis of the bottom-up and top-down processes in listening. In this interactive process, listeners interactively employ their phonological, syntactic, semantic, and pragmatic knowledge to decode the meaning of the listening texts. Such a model, from a pedagogical perspective, allows flexibility and sensitivity to individuals' learning styles as well as listening levels (Flowerdew \& Miller, 2005).

\section{Listening instruction: why, what and how?}

Given the well-established role that the listening skill plays in language learning, the key questions that emerged have been whether the skill is teachable and if yes, what contents should be included in teaching and how teaching should be implemented. While to a certain extent, listening could be seen as an individuals' internal skill (Wilson, 2016) and its development and mastery appears to rely on learners' effort and practice, there is much teachers could do to teach and help students develop their listening skill. Wilson (2016), for instance, maintains that teachers can guide students towards more efficient listening through the teaching of strategies and provide "continual exposure to appropriate listening material with carefully sequenced practice activities" (p. 21). Vandergrift and Goh (2018) further suggest that teachers, with a good understanding of the mental and learning processes their learners engage in to achieve comprehension, can plan lessons that "reveal these processes and make students more aware of these processes" (p.126) as well as the internal and external factors that might impact their listening performance. Furthermore, Ridgway (2000) points out that abundant listening activities can enhance not only their listening skills but also the automaticity in the oral language process while Harmer (2001) contends that learners' acquisition of the target language could be effectively facilitated when they approach the language in use via listening. In general, there is a consensus among listening experts (Flowerdew \& Miller, 2005; Vandergrift \& Goh, 2018; Wilson, 2016) that with lessons designed in a theoretically principled manner, teachers can effectively help students improve their listening competence through classroom teaching.

In teaching listening, however, one of the central issues that needs to be considered is its subject matter content knowledge; what specific contents should be included in listening lessons. It should be acknowledged that attention to this aspect appears to be limited in the current literature. In most existing publications that provide teachers with guidance on listening pedagogy, attention is more drawn towards pedagogical models, listening processes and strategies, and curriculum, syllabus, and material development. Having said that, an overview of the literature focusing on features of listening texts and types of meaning for listening reveals a volume of important content components that need to be covered in listening instruction. Flowerdew and Miller (2005), for instance, reckon that five main types of knowledge need to be drawn on for the comprehension of a spoken message including "phonological - the sound system; syntactic - how words are put together; semantics - word and propositional knowledge; and pragmatic - the meaning of utterances in particular situations" and "kinesic knowledge, which is conveyed by the facial and bodily movement of the speaker" (p. 30).

Similarly, when discussing features of a good listening text, Wilson (2016) suggests a cluster of content components that deserve close attention in listening teaching, including speech acts, discourse structures, grammar, vocabulary, and pronunciation. To some extent, these components could be seen as specifications of what Flowerdew and Miller (2005) suggest above. In the same vein, in discussing factors determining learners' development and success in listening ability, Vandergrift and Goh (2018) propose a comprehensive group of knowledge and skills learners need to focus on, which includes lexical, syntactic, discourse, pragmatic and metacognitive knowledge. They further emphasize the role of learners' prior knowledge of specific topics or schemata as well as listening skills and strategies. In support of Richards' (1983) proposal for an inventory of micro-listening skills, they specifically propose a list of six core skills that are considered as integral to the listening process that teachers should employ for planning listening lessons, including listening for details, 
DOI: $\underline{10.51386 / 25815946 / \mathrm{ijsms}-\mathrm{v} 4 \mathrm{i} 5 \mathrm{p} 102}$

listening selectively, listening for global understanding, listening for main ideas, listening and inferring, and listening and predicting (Vandergrift \& Goh, 2012, 2018). This brief overview of the listening subject matter content seems to indicate that although linguistic components are seen as core instructional contents, they are not sufficient to support student's comprehensive development. Rather, teachers need to systematically plan for lessons that incorporate linguistic contents with other aspects including topical knowledge, listening strategies, knowledge of discourse, semantics, pragmatics, and metacognition.

With regards to the question of how listening lessons should be designed and structured, a number of proposals exist in the literature. Among them, the most comprehensive overview of approaches to the teaching of the listening skill is provided by Vandergrift and Goh (2018). They outline three key approaches: (1) text and comprehension, (2) communication and comprehension, and (3) learner awareness and the listening process. The text and comprehension approach is viewed as a conventional model with its strong focus on decoding sounds, listening to, imitating and memorizing sounds and grammar patterns, and identifying relevant details from the input. The key objective in this approach is to have learners demonstrate their local and global understanding of the meaning of the listening texts. In this sense, this approach seems to be similar to the research of Field (2008) when he suggests the traditional product-oriented approaches to listening instruction. In the communication and comprehension approach, key focuses are placed upon students' ability "to understand information appropriate to the purposes of the spoken texts, practice main and sub-listening skills and respond to spoken input in socially appropriate ways" (Vandergrift \& Goh, 2018, p. 147). Finally, in learners' awareness and the listening process approach, apart from a strong focus on learners' ability to comprehend listening texts in a communicatively appropriate manner, a stronger focus is placed upon the learners' metacognitive awareness and their ability to employ appropriate strategies for comprehension. Among these approaches, the learners' awareness and the listening process one are currently viewed as the most comprehensive model that addresses various aspects that learners are required to pay attention to in listening learning and development.

In alignment with this updated approach, Vandergrift and Goh (2018) further propose four different forms of lesson structures that reflect the process-oriented listening instruction. These include (1) metacognitive pedagogical sequence with five lesson stages; (2) process-based reflections and discussions with three stages; (3) task-based metacognitive instruction with communicative listening tasks framed by metacognitive activities in the pre- and post-listening stages, and (4) scaffolded extensive listening projects which integrate listening practice beyond the classroom context (for more details of these lesson models, see Vandergrift and Goh, 2016). As they contended, these lesson models allow teachers to draw students' attention more towards the interactive and communicative aspects in listening, integrate both bottom-up and top-down processes, tap into a range of listening skills and strategies that are crucial for listening development and success as well as enable them to gradually develop their metacognitive awareness and skills for effective listening learning. In other words, these updated models encourage listening teachers to depart from the traditional product-oriented teaching and lean more towards the process-oriented side.

With regard to empirical research that focuses on the teaching of listening skill, although in general, a limited number of studies are available, findings from these studies establish important bases for understanding the reality in teaching this particular skill in various contexts. For instance, in a study of 10 EFL teachers in Japan, Joseph and Siegel (2013) found that these teachers leaned more towards the product-based teaching approach. Similarly, in resonance with Chambers's (1996) and Field's (2008) observations on the teachers' reliance on the "Comprehension Approach" (Field, 2008), Graham et al. (2014) and Graham and Santos (2015), in their studies with English teachers reported on similar results, confirming that the teachers paid closer attention to task completion procedures, rather than focusing on improving listening skills for learners. In another study conducted by Siegel (2014) with teachers in Japan, it was found that teachers tend not to teach listening because they lack pedagogical knowledge. In the Vietnamese context, the majority of studies conducted previously seem to draw attention mainly to either the learners' difficulties in listening performance (e.g., Nguyen \& Thai, 2018; Duong \& Chau, 2019; Tran \& Duong, 2020) or teachers' practice in teaching and developing learners' listening strategies (Dao, 2013; Luu \& Phung, 2013; Vo, 2014; Ngo, 2016;). Research that directly investigates the teachers' pedagogical practices in teaching the listening skill in this context, however, appears to be neglected. 
DOI: $\underline{10.51386 / 25815946 / \mathrm{ijsms}-\mathrm{v} 4 \mathrm{i} 5 \mathrm{p} 102}$

\section{RESEARCH METHODOLOGY}

\section{A. Research method}

To explore the teachers' perceptions, stated and actual practices in teaching the listening skill in a particular context of a Vietnamese university, the current study employed a qualitative research design with data collected via semi-structured interviews and classroom observations. This qualitative design was utilized and viewed as most suitable for its power in allowing the researchers to probe into the teachers' inner experience and in-depth beliefs together. It also enables the researchers to figure out how meanings and behaviors are shaped through and in culture or specific contexts (Corbin \& Strass, 2008). The interviews in this study were designed to explore the teachers' perceptions of the importance of the listening skill as well as their stated practice in teaching this particular skill. These interviews help uncover the richness and complexity of the participants' thinking, experiences, and beliefs (Maynard, 2002). Along with the interviews, classroom observations allowed the researchers to obtain evidence in relation to the participants' actual classroom practice in listening instruction. Classroom observation data, as such, serve both as key evidence for the exploration of how the teachers enacted listening instruction to their students in reality and as triangulations for what they stated in their interviews.

\section{B. Participants}

Six EFL teachers (Male: teachers 3, 5, 6; Female: teachers 1, 2, 4) working in a university in the Mekong Delta, Vietnam participated in the study. These six teachers were among 12 teachers in this university who were teaching listening and speaking to English-majored students who were willing to participate. In the semester data were collected for the study, these teachers were teaching a mixture of three cohorts of students: English Studies (General and High-Quality programs), English Translation and Interpretation, and English Teacher Education. These student groups represent a wide range of the university's English-majored students, spanning from freshmen to sophomore to junior and senior groups. In terms of qualifications, one of the participants held a Doctoral degree (Teacher 3) while the other five all got a Master's degree. With respect to teaching experience, these teachers had a minimum of 2 years of teaching listening and speaking courses at the university with the most senior teachers having 12 years of experience.

\section{Instruments}

\section{1) Semi-structured interviews}

As earlier mentioned, interviews were employed in this study to explore the teachers' perceptions of the importance of the listening skill and their stated practice in teaching listening. Accordingly, a semi-structured interview protocol (Appendix 1) was designed with 8 question items. Question 1 required the teachers to provide their personal information and years of experience in teaching the listening skill at the university. Question 2 and 3 focused on exploring their perceptions of the importance of the listening skill to their students and their specifications of the objectives they set in listening instruction. Following this, questions 4 to 8 focused on three aspects of the teachers' reported practice namely the contents they prioritized in their listening lessons (questions 4 and 5), what typical lesson structure they designed (question 6), and what activities they typically employed in their listening classes (questions 7 and 8). Six interviews were conducted with individual teachers with each interview lasting from 25 to 40 minutes. The teachers were allowed to choose either to be interviewed in English or Vietnamese as long as they felt most convenient and confident to share the most indepth information as they could. As a result, 5 interviews were conducted in Vietnamese and one was in English. All six interviews were then transcribed and translated into English and co-coded by the researcher, his supervisor, and the researchers' classmates.

\section{2) Classroom observations}

Observations were conducted with all six teacher participants, aiming to explore their actual classroom practice in listening instruction. Accordingly, for each teacher, observations were done with one full unit, which was typically divided into two teaching sessions (two 50-minute periods/ each session). However, due to the researcher's tight schedule during the Covid-19 period, only one observation was conducted with Teacher 3 . Also, for Teachers 5 and 6 , one of the two lessons observed was mainly focused on students' presentations, so these two sessions were not included in the data set for the study. As a result, a total number of 9 lessons 
DOI: $\underline{10.51386 / 25815946 / \mathrm{ijsms}-\mathrm{v} 4 \mathrm{i} 5 \mathrm{p} 102}$

observed were officially documented for the study. When observing, the researcher took the position of a nonparticipant using a field note form to record all activities happening in the lessons. As can be seen in Appendix 3 , the field notes allowed the researcher to record all information related to the lessons including topics, the number of students, setting of the classroom, lesson stages, activities in each lesson stage, content focus in each activity as well as specific teacher's and learners' tasks in each lesson stage. All the observed lessons were then transcribed and coded. A cross-analysis table (Appendix 4) was developed with all contents, stages, and activities included in each of the nine lessons synthesized. Based on this cross-analysis table, the researcher generalized the typical lesson structure employed by the teachers and figured out the typical activities they employed for each lesson stage.

\section{FINDING AND DISCUSSION}

In this section, the main findings from the study will be reported in accordance with the three research questions around which the study was central. However, rather than sticking to the research questions, the main themes revealed by key findings in relation to each research question will be employed and presented as subtitles in this section. As also earlier explained, the central focus in the exploration of the teachers' reported and classroom practices in this study (for research questions 2 and 3) was drawn toward three key aspects of the specific contents the teachers prioritized in their listening instruction, their typical listening lesson structure and the activities they typically employed for their listening lessons. Findings in relation to these two research questions will be organized in accordance with these specific focuses with evidence from both interviews and classroom observations cited to support the findings.

\section{A. Teachers'perceptions of listening mainly as an input source for language learning}

The first aspect that the current study aimed to explore was the teachers' view of the importance and the role of listening in the program they were teaching and their students' language development. Evidence from the teachers' interviews clearly indicated that all the participants were fully aware of the crucial role of the listening skill to their students. Teacher 5, for instance, stated that "listening is one of the ultimate goals in language teaching and learning" (Lines 574-575) while Teacher 2 confirmed that in teaching, "it is critical to demonstrate to pupils what constitutes listening" (Lines 150-151). Similarly, Teachers 1 and 3 reconfirmed that listening played a critical role in the language program they were teaching while Teacher 4 highlighted the role of listening in communication as justifications for the importance of this particular skill, saying "I think nowadays listening and speaking skills are very important that all English teaching and learning activities are aiming for because they support other language skills" (Lines 433-435). It means that all the teachers appeared to hold a common belief that listening skill is an important skill for learners to master as part of their language learning program.

Given this full awareness of the important role that listening plays in the students' language learning process, it should be noted that these teachers had a tendency to view listening mainly as a source of language input, rather than as an independent macro-language skill for students to master. In other words, they regarded listening lessons mainly as a source of input through which ideas, vocabulary, pronunciation, and topics or situations for speaking practice were provided. For instance, Teacher 3 disclosed that "listening is not just listening as it can help develop other skills" (Lines 290-291). Similarly, Teacher 5 said that "it's [listening skill] indispensable as speaking input" while Teacher 1 even specified that "listening provides input of vocabulary and ideas for speaking" (Lines 576-577). In the same vein, Teacher 4 remarked that "listening is a means for improving speaking and vocabulary" (Lines 434-435). She further linked listening with other skills such as speaking and writing and emphasized its role as "complement", saying:

These days, I am certain that listening and speaking skills are particularly crucial since it complements other skills. For example, when I teach pupils to listen, they can speak more fluently or have a larger vocabulary to write more effectively. (Teacher 4, lines 433-435)

Holding such a perception towards the role of listening skill as an input source for language learning, six teachers acknowledged that listening skill was a fundamental component in their teaching. Some teachers also highlighted practical reasons for a strong focus on this particular skill in their teaching. To exemplify, Teacher 
DOI: $\underline{10.51386 / 25815946 / \mathrm{ijsms}-\mathrm{v} 4 \mathrm{i} 5 \mathrm{p} 102}$

2 shared that 'my pupils' speaking skills are better than their listening skills. However, when it comes to listening, a handful of students encounter several difficulties when practicing" (Lines 148-149). Teacher 2 recalled and described: "it's not smooth, there's no fluency, and it's not as advantageous as speaking" (Lines 149-150). Holding such a belief, she perceived a strong need to draw more attention to the listening skill in teaching. For her, "it is essential to teach them what effective listening skills are" (Lines 150-151). Sharing a similar thought, Teacher 6 emphasized that "given the essential role that listening plays, we are trying to deliver the skills so that students would feel more confident in listening" (Lines 696-697). A similar belief was also evident in Teacher 5's sharing:

For this moment, listening and speaking are the two skills that all English teaching and learning activities are aiming for. Everywhere I go, I listen to communication so I think teaching listening is very important. Besides, when teaching the listening part in some programs, it is like the input for the speaking part; hence, teaching listening is indispensable. (Teacher 5, lines 574-577)

As evident in the teachers' reasoning, listening was perceived to be a crucial skill to be addressed in their teaching context, not only because they considered this skill as an indispensable source of input, but also because of their views of the problems that their students encountered in listening performance. All the teachers, as such, supported that listening was a must-teach skill in the program. To a large extent, this general finding reflects a high level of similarity with Nunan's (1998) and Rubin's (1995) suggestion that listening is the most basic skill in language learning or should be viewed as the key to knowing a language (Wilson, 2016). Although it is sensible to acknowledge listening as a key input source in the language learning process, what seems to be missing from these teachers' sharing is the awareness that this skill itself should be viewed as an important independent macro-language skill that learners are expected to master. In other words, to a great extent, the teachers seemed not to think about listening as a vital learning content with a set of knowledge and skills that need to be introduced and taught to the students.

This extreme perspective on listening simply as a complement to other skills for language acquisition and the input for the speaking part might affect the teachers' teaching, which in turn, might result in insufficient attention to certain contents that are important for students listening development. Such a reality has been highlighted by Graham et al., (2014), emphasizing that listening activities still take place in the classroom but not much learning might happen. In such a teaching and learning context, the guidance and scaffolding required to help students "understand and develop the processes of listening so that they can develop their listening comprehension explicitly and systematically (Vandergrift \& Goh, 2018, p. 124) might not be in place. Problems have been raised with such a practice, warning that even though plenty of listening activities might take place in these classrooms, listening skills and processes are not actually taught and listening activities merely supply learners with regular spoken input to practise "without much in the way of informed teaching and learning opportunities" (Vandergrift \& Goh, 2018, p. 146). This finding suggests that endeavors to improve the effectiveness in listening teaching and learning in this context might need to be addressed, first of all, from the task of broadening the teachers' view of listening from exclusively as an input source to a more balanced angle where listening is also seen as an independent macro-language skill that needs to be explicitly taught in a principled manner.

\section{B. Vocabulary, topical knowledge and listening strategies: three top prioritized teaching contents in listening instruction}

The first pedagogical aspect that the study aimed to explore in relation to the teachers' reported and actual practices in listening instruction was the specific content they prioritized in their listening lessons. Evidence from both interviews and classroom observations revealed that three particular components comprising vocabulary, topical knowledge or ideas, and listening strategies occupied a central position in these teachers' lessons. As presented in Table 2, a total of six specific contents were mentioned by the participants including vocabulary, topical ideas, grammar, pronunciation, note-taking, and listening strategies. However, only three components namely vocabulary topical knowledge and listening strategies were consistently mentioned by all six teachers. Meanwhile, pronunciation was mentioned only by teachers 1,2 , and 4 whereas grammar and notetaking skill each were mentioned by two teachers (Teachers 1 and 4; Teachers 1 and 2, respectively). 
DOI: $\underline{10.51386 / 25815946 / \mathrm{ijsms}-\mathrm{v} 4 \mathrm{i} 5 \mathrm{p} 102}$

\section{TABLE I}

TEACHERS' PRIORITIZED CONTENTS IN REPORTED PRACTICE

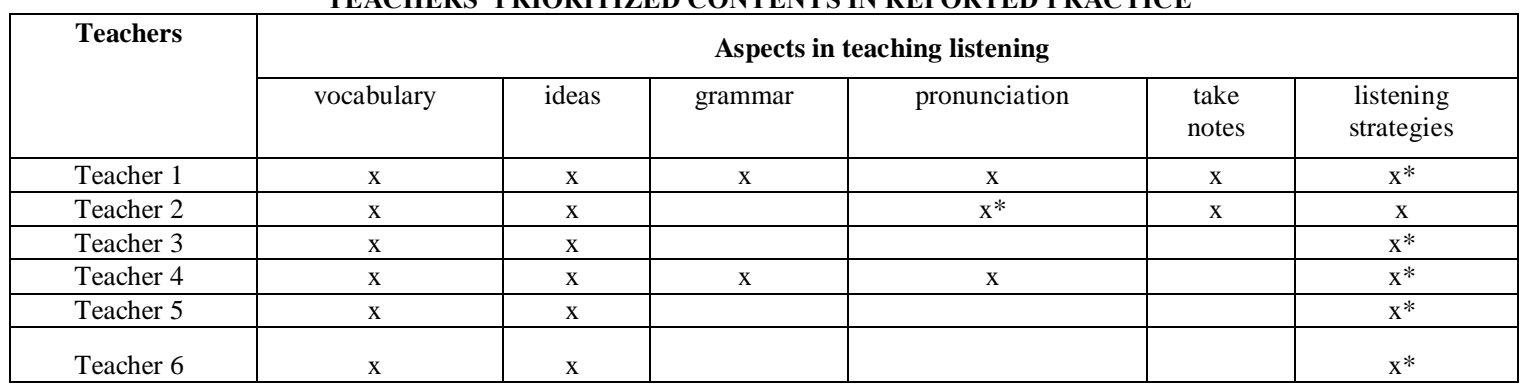

Note: $\mathrm{x}$ : aspect teachers mentioned to focus/ *: the most important aspect

Data from the observations appeared to support a similar prioritization upon these same three contents in classroom practice. As shown in Table 2, vocabulary, topical ideas, and listening strategies were included in all 09 observed lessons. Grammar, however, was found to be covered in only two lessons while pronunciation and note-taking were not evident in any observed lessons. In particular, in each of the observed lessons, there was at least one part devoted to the teaching of vocabulary in the pre-listening for which the teachers used different techniques. For example, Teachers 1, 2, 4, and 6 (in lessons 1, 2, 3, 4, 7, 9) mainly relied on the readily designed matching vocabulary activities in the textbooks whereas Teacher 5 introduced a group of vocabulary about energy sources from a video taken from Youtube. Still, Teacher 6 told a story of Romeo and Juliet to lead students to the target vocabulary.

As the teachers elaborated in the interviews, in every listening lesson, it was their main duty to assist students in segmenting the listening text to understand ideas by unpacking the meaning of important vocabulary. They also contended that it was their important task to help students identify key ideas and words that students then should extract and learn so that they could, later on, apply in other skills such as speaking or writing. In other words, this finding reaffirms the teachers' common perception of listening mainly as a means for supplying input for language learning and development. As Teacher 5 contended, without suitable vocabulary, "learners will get bored when they listen" (Line 614); thus, they may "fail to complete the tasks given by their teachers." Teacher 4 further suggested that vocabulary must be "related to the listening track [content]" (Lines 611-612) and learners should be provided with opportunities to "do exercises in the book to improve their ranges of vocabulary" (Line 611). Some other teachers had a tendency to dovetail vocabulary with pronunciation as the key input to "aid them [students] to listen more effectively" (Lines 37-38). Teacher 2, for instance, explained that vocabulary and pronunciation of these words together built a firm foundation for learners' listening enhancements. As such, in teaching, it was important to "provide unfamiliar vocabulary and include the pronunciation of that word, and ask a few students to read it again and make sure they already know the meaning and how to read it" (Lines 191-192).

\section{TABLE II}

\section{TEACHERS' PRIORITIZED CONTENTS IN CLASSROOM PRACTICE}

\begin{tabular}{|c|c|c|c|c|c|c|c|c|c|}
\hline \multirow[t]{2}{*}{ Steps } & \multicolumn{2}{|c|}{$\begin{array}{c}\text { Teacher } \\
1\end{array}$} & \multicolumn{2}{|c|}{$\begin{array}{c}\text { Teacher } \\
2\end{array}$} & \multirow{2}{*}{$\begin{array}{c}\text { Teacher } 3 \\
\text { Lesson } \\
5 \\
\end{array}$} & \multicolumn{2}{|c|}{$\begin{array}{c}\text { Teacher } \\
4\end{array}$} & \multirow{2}{*}{$\begin{array}{c}\text { Teacher } 5 \\
\text { Lesson } \\
8 \\
\end{array}$} & \multirow{2}{*}{$\begin{array}{c}\text { Teacher } 6 \\
\text { Lesson } \\
9 \\
\end{array}$} \\
\hline & $\begin{array}{c}\text { Lesson } \\
1\end{array}$ & Lesson 2 & Lesson 3 & Lesson 4 & & Lesson 6 & Lesson 7 & & \\
\hline Vocabulary & $\mathrm{X}$ & $\mathrm{X}$ & $\mathrm{X}$ & $\mathrm{X}$ & $\mathrm{X}$ & $\mathrm{X}$ & $\mathrm{X}$ & $\mathrm{X}$ & $\mathrm{X}$ \\
\hline Topical ideas & $\mathrm{X}$ & $\mathrm{X}$ & $\mathrm{X}$ & $\mathrm{X}$ & $\mathrm{X}$ & $\mathrm{X}$ & $\mathrm{X}$ & $\mathrm{X}$ & $\mathrm{X}$ \\
\hline Grammar & & & & & $\mathrm{X}$ & & $\mathrm{X}$ & & \\
\hline Pronunciation & & & & & & & & & \\
\hline Note-taking skill & & & & & & & & & \\
\hline $\begin{array}{l}\text { Listening } \\
\text { strategies }\end{array}$ & $\mathrm{X}$ & $\mathrm{X}$ & $\mathrm{X}$ & $\mathrm{X}$ & $\mathrm{X}$ & $\mathrm{X}$ & $\mathrm{X}$ & $\mathrm{X}$ & $\mathrm{X}$ \\
\hline
\end{tabular}

In addition to vocabulary, topical knowledge was also found to be one of the top prioritized contents in the teachers' practices. Observation data informed that providing students with enough ideas for speaking appeared to be of crucial importance. As commonly designed, most of the teachers' lessons ended with a speaking production activity where the teachers expected their students to perform the input of vocabulary and ideas that 
DOI: $\underline{10.51386 / 25815946 / \mathrm{ijsms}-\mathrm{v} 4 \mathrm{i} 5 \mathrm{p} 102}$

they provided in previous parts of the lessons in this speaking task performance. As such, the teachers appeared to carefully select ideas related to the topic under discussion, either in the pre-listening stage through the supplemented videos, reading material, and discussion activities or the main listening texts from the prescribed materials.

The third content that was found to be consistently included in these teachers' lessons was listening strategies. However, the teachers' explanation about listening strategies seemed to show a certain level of discrepancy in what they referred to by this term. For instance, Teachers 1, 4, and 5 employed this term to refer to testing or exam strategies that students should use in order to approach the listening activities or tasks effectively. Teacher 1 specifically mentioned these strategies for doing "listening exercises or tests" while Teachers 4 and 5 repeatedly mentioned different types of tests such as IELTS and specific listening task types such as multiple choice or gap-filling when discussing these listening strategies. In all observed lessons, listening strategies occupied an important position in the while stage where the teachers guided students to do the listening tasks. During this stage, along with helping students segment and decode the language in the listening texts for understanding, complete the listening exercises with all answers checked and explained, the teachers also paid close attention to explaining how different forms of listening tasks or question types could be effectively approached. Besides these three main contents, other linguistic knowledge such as grammar and pronunciation were found to be largely neglected in these teachers' lessons. Among the teachers, only Teachers 3 and 4 included a small part in their lessons that focused on structural knowledge. There was no separately designed lesson part in which taking notes and pronunciation occupied central positions as the target teaching contents.

In a nutshell, evidence from both interviews and observations showed that the three components of vocabulary, topical knowledge, and listening strategies occupied a central position as key teaching contents in these teachers' listening lessons. The teachers' top priority on vocabulary in listening instruction appears to be strongly supported from both theoretical and research standpoints. Rivers and Nunan's (1991), for instance suggest that having massive vocabulary is crucial for successful second language use and thus should be focused on the teaching. Research evidence reported by Mecartty (2000), Bonk (2000), Vandergrift and Baker (2015) all pointed out that vocabulary knowledge was found to be the most important factor or the strongest predictor of L2 listening success. Furthermore, the teachers' prominent focus on topical knowledge to ensure that their students had sufficient ideas to engage in the speaking production at the end of the lessons reaffirms what Nguyen (2018) reported in his study about the common practice of teachers in this same context, informing that one typical problem in speaking for students in Vietnamese setting is their lack of ideas for discussion and conversations. As such, teachers in this context seem to care much about preparing their students with enough ideas for speaking. Topical knowledge, as a result, is seen as an indispensable input in their language lessons.

The teachers' explanations of what they meant by listening strategies, however, seemed to hint at a gap in their understanding of the issue that needs to be soon updated. As earlier discussed, the majority of the teachers appeared to use the term strategies to refer to tips or tactics learners should rely on to best approach listening tasks in exams or tests. Limited attention, however, was paid to important listening micro-skills or strategies that learners need to be introduced to and develop in a systematic manner. Undue attention paid to these strategies might lead to limited development in students' listening ability. As Richards (2005) contends, for example, students' mastery of discrete skills or micro-skills in listening such as discriminating sounds in words, deducing the meaning of unfamiliar words, differentiating facts and opinions, or noting contradictions is of crucial importance for effective listening. Similarly, a repertoire of specific listening strategies was provided by Brown (1990), Richards (2005), Field (2008), and Vandergrift (2003) that need to be focused on in listening instruction. Updating teachers in this context with a more comprehensive picture of listening strategies might be a fruitful, practical action to take in the joint effort to improve the quality of listening instruction.

In addition, the fact that the teachers seemed to downplay the role of other important components of listening subject matter content is worth noticing. Although vocabulary knowledge, topical knowledge, and listening strategies have a crucial role to play, an exclusive focus on these contents might restrict the development of learners' listening ability. Vandergrift and Goh (2018), for example, point out that besides lexical and prior knowledge, knowledge of discourse, syntax, pragmatics, and metacognition all has its contributing role to play in listening success. Brown (1990) also proposes a taxonomy of listening micro-strategies that teachers need to systematically address in listening instruction. As such, in attempts to prepare teachers in this context for more 
DOI: $\underline{10.51386 / 25815946 / \mathrm{ijsms}-\mathrm{v} 4 \mathrm{i} 5 \mathrm{p} 102}$

listening teaching effectiveness, professional development activities that help them obtain a holistic view of the listening subject matter content should be viewed as the top priority.

\section{The dominance of the three-stage lesson structure: Pre-, While- and Post-listening}

The second major pedagogical aspect that this study was designed to explore was the teachers' lesson structure. In other words, it examined the typical lesson design and sequence that the teachers employed for their listening classes. As consistently evident in interviews and observations, all the participants appeared to align with a typical lesson model with three stages: Pre, While and Post- listening. Evidence also indicated that in each of these stages, the teachers focused on similar purposes although the activities they used could be varied. For instance, for the pre-listening stage, Teacher 1 stated that her main focus was placed upon "establish[ing] the aim" (Line 61) so that students could recognize "what the purpose of listening is" (Line 61). She believed that this stage was essential for students to comprehend "the aim of the listening" (Line 62) since it would help students effectively approach the listening tasks. Holding the same opinion, Teacher 5 reported to have concentrated on guiding "students to anticipate the listening context" (Line 610). Teacher 6 shared the same perspective, stating that pupils must be capable of "predicting the listening context" (Line 610) to provide more effective listening production. Teachers 2 and 3, however, seemed to place more focus on teaching vocabulary. Teacher 2, for instance, anticipated that she would "supply novel vocabulary with the pronunciation" and "had a few of her pupils repeat it out" (Line 192) while Teacher 3 highlighted the role of vocabulary by "providing words linking to the material" (Lines 315-316) so that "students are not astonished" (Lines 320-321) when they learn. As a whole, it appeared that for six participants, the main goals of the pre-listening stage were central among the tasks of introducing the topic, setting the context, providing background information related to the topic, and teaching vocabulary to prepare students for the upcoming listening activities in the while-stage.

Following this, in the while-stage, the teachers primarily drew students' attention to the implementation of the main listening tasks, mostly from the prescribed textbooks. In guiding the students to conduct the listening activities, the teachers' priority, however, seemed to be drawn towards the task completion rather than the development of the students' listening ability. In other words, the primary focuses in this stage were placed upon helping students understand the tasks, segment the listening texts, decode the meaning and get the correct answers. With these objectives in mind, the teachers felt a strong need to help students not only select the right answers but also provide justifications for their options, which they perceived as evidence of students' thorough understanding of the listening texts. Teacher 1, for example, shared that she would "allow pupils to take notes" (Lines 90-91) to "complete the textbook exercises" (Line 91) whereas Teacher 2 would also typically "ask pupils to take notes" (Lines 194-195) so that they could "comprehend the main ideas" (Line 194) during the while-listening section. Likewise, Teacher 5 would have students "write notes on what they've heard" so that they could "figure out what the recordings are about" (Line 662). Teacher 3 further explained that she would help students process and comprehend the listening texts by having them "read what they are about to hear carefully, underline keywords and exam requirements so that the learners know what they will do." (Lines 512513). This evidence indicated that although the teachers might have students focus on doing different activities in this stage, they all shared the same purposes- having students conduct the listening tasks and ensuring the students understand the texts and get the correct answers for the exercises. The end of this while-stage was, thus, typically marked by an answer checking activity when the teachers usually had individual students explain their answers to the questions.

In the final stage, the teachers focused on helping students consolidate the content in the lesson and apply what they have learned in speaking production. In particular, Teacher 1 recommended that pupils summarize the listening content, and "if pupils are passive" (Line 94), she would ask them to "answer questions about the lesson" (Line 94) to support them in the summary. Teacher 2 also stated that she would "give pupils a summary in the form of a map" (Lines 355-356) and then "share it with people around" (Line 356) while Teacher 3 shared that he would review any important structures, or share his listening experience. Similarly, Teacher 6 described that at the end of the listening part, he would encourage students to "reflect on what they learn about it." (Line 713). Teacher 5, however, said that he might use different speaking production activities in this stage including summarizing, role play or presentation, or other activities related to listening. All in all, in this final 
DOI: $\underline{10.51386 / 25815946 / \mathrm{ijsms}-\mathrm{v} 4 \mathrm{i} 5 \mathrm{p} 102}$

Volume: 4 Issue: 5

September to October 2021

https://www.ijsmsjournal.org

stage of the lesson, the teachers had a tendency to encourage their students to transfer the input they have gained from the listening parts into production, especially in speaking form.

In consistency with findings from the interview data, evidence from the nine observed lessons reconfirmed the three-stage lesson structure that the teachers described in the interviews. As depicted in Table 3, except for lessons 2 and 5 in which a post-listening stage was missing, the other seven lessons featured a consistent structure of three stages: pre-listening, while-listening, and post-listening. In particular, each lesson began with the pre-listening stage in which the teachers warmed up, introduced the topic, set the context for the new lessons, provided students with new necessary background knowledge and pre-taught vocabulary to prepare them for the main listening tasks. Then, in the while-listening stage, most teachers prepared students for the listening tasks by having them read the questions, analyze the keywords, predict the answers, and refocus before listening. Following this, students had two times of listening to the recordings before answering for the exercises and explanations for the answers were provided either by the teachers or the students under the teachers' guidance. Finally, students engaged in a speaking production activity which could be in the form of discussion, debate, presentation, description or simply summarising.

TABLE III

CROSS ANALYSIS OF OBSERVED LESSONS REGARDING THE LISTENING LESSON STRUCTURE

\begin{tabular}{|c|c|c|c|c|c|c|c|c|c|c|}
\hline \multirow[t]{2}{*}{ Stages } & \multirow[t]{2}{*}{ Steps } & \multicolumn{2}{|c|}{ Teacher 1} & \multicolumn{2}{|c|}{ Teacher 2} & \multirow{2}{*}{$\begin{array}{c}\text { Teacher } 3 \\
\text { Lesson } \\
5 \\
\end{array}$} & \multicolumn{2}{|c|}{ Teacher 4} & \multirow{2}{*}{$\begin{array}{c}\text { Teacher } \mathbf{5} \\
\text { Lesson } \\
8 \\
\end{array}$} & \multirow{2}{*}{$\begin{array}{c}\text { Teacher } 6 \\
\text { Lesson } \\
9\end{array}$} \\
\hline & & $\begin{array}{c}\text { Lesson } \\
1\end{array}$ & $\begin{array}{c}\text { Lesson } \\
2\end{array}$ & $\begin{array}{l}\text { Lesson } \\
3\end{array}$ & $\begin{array}{c}\text { Lesson } \\
4\end{array}$ & & $\begin{array}{l}\text { Lesson } \\
6\end{array}$ & $\begin{array}{c}\text { Lesson } \\
7\end{array}$ & & \\
\hline \multirow{4}{*}{$\begin{array}{c}\text { PRE- } \\
\text { LISTENING }\end{array}$} & Warm-up & $\mathrm{X}$ & & & & & & & & \\
\hline & $\begin{array}{l}\text { Lead-in the } \\
\text { topic }\end{array}$ & $\mathrm{X}$ & $\mathrm{X}$ & $\mathrm{X}$ & $\mathrm{X}$ & $\mathrm{X}$ & $\mathrm{X}$ & $\mathrm{X}$ & $\mathrm{X}$ & $\mathrm{X}$ \\
\hline & $\begin{array}{l}\text { Set the } \\
\text { context }\end{array}$ & $\mathrm{X}$ & $\mathrm{X}$ & $\mathrm{X}$ & $\mathrm{X}$ & $\mathrm{X}$ & $\mathrm{X}$ & & $\mathrm{X}$ & $\mathrm{X}$ \\
\hline & $\begin{array}{c}\text { Pre-teach } \\
\text { vocabulary }\end{array}$ & $\mathrm{X}$ & $\mathrm{X}$ & $\mathrm{X}$ & $X$ & $\mathrm{X}$ & $\mathrm{X}$ & $\mathrm{X}$ & $X$ & $X$ \\
\hline \multirow[t]{3}{*}{$\begin{array}{c}\text { WHILE- } \\
\text { LISTENING }\end{array}$} & $\begin{array}{c}\text { Prepare } \\
\text { learners for } \\
\text { listening }\end{array}$ & & $\mathrm{X}$ & & $\mathrm{X}$ & $\mathrm{X}$ & $\mathrm{X}$ & $\mathrm{X}$ & $\mathrm{X}$ & $\mathrm{X}$ \\
\hline & $\begin{array}{c}\text { Main } \\
\text { listening } \\
\text { tasks }\end{array}$ & $\mathrm{X}$ & $\mathrm{X}$ & $\mathrm{X}$ & $\bar{X}$ & $\mathrm{X}$ & $\mathrm{X}$ & $\mathrm{X}$ & $\mathrm{X}$ & $\mathrm{X}$ \\
\hline & $\begin{array}{c}\text { Answer } \\
\text { checking \& } \\
\text { explanations }\end{array}$ & $\mathrm{X}$ & $\mathrm{X}$ & $\mathrm{X}$ & $\mathrm{X}$ & $\mathrm{X}$ & $\mathrm{X}$ & $\mathrm{X}$ & & $\mathrm{X}$ \\
\hline $\begin{array}{c}\text { POST - } \\
\text { LISTENING }\end{array}$ & $\begin{array}{c}\text { Speaking } \\
\text { production* }\end{array}$ & $\begin{array}{l}\text { DIS } \\
\text { PRO }\end{array}$ & --- & SUM & $\begin{array}{l}\text { SUM } \\
\text { DIS }\end{array}$ & --- & DIS & DES & $\mathrm{PIC}$ & DEB \\
\hline
\end{tabular}

(*) DIS: Discussion/PRO: Project/SUM: Summarize/DES: Describe/ PIC: Picture tasks/DEB: Debate

These findings in relation to the teachers' typical lesson structure suggest three important points. First, it shows a high level of convergence between the teachers' reported practice or what they claimed to have done and what they actually enacted in the classroom. Second, it seems to signal a certain extent of the teachers' alignment with the Presentation, Practice, and Production (PPP) lesson model that has been reported to be dominant in the Vietnamese context for decades (Canh, 2007, 2011; Canh \& Barnard, 2009; Nguyen, 2018; Nguyen, 2014). These teachers' lessons, however, also appeared to move beyond the conventional PPP model to further incorporate speaking production activities in the final stage, and the focus of these lessons was placed more on the lexical and topical knowledge rather than grammatical structures. It means that the teachers' lessons also appeared to reflect a clear resemblance to the traditional product-oriented approach. As Vandergrift and Goh (2018) suggest, such a practice might lead to limited learning outcomes unless the teachers soon update themselves with a more process-oriented teaching model that allows them to address listening instruction in a more holistic manner. Third, in terms of the listening approach, the teachers seemed to combine both top-down and bottom-up approaches in their lessons. In particular, in order to help students unpack the listening texts, the teachers gradually led students through the topic introduced at the beginning of the lessons by scaffolding necessary linguistic input and topical knowledge to build up students' understanding of the topic to prepare for listening. However, in the while-stage, the teachers also spent much time on helping students segment and decode language and figure out meanings at word, sentence, and text levels, which gradually help them build up 
DOI: $\underline{10.51386 / 25815946 / \mathrm{ijsms}-\mathrm{v} 4 \mathrm{i} 5 \mathrm{p} 102}$

their understanding of the texts. This combined approach appears to match what Field (2004), Brown (2006), and Newton and Nation (2020) suggest, which highlights that listening integrates the student's prior knowledge of the subject with what they hear during the listening process (Newton \& Nation, 2020). It also has resonance with what Flowerdew and Miller (2005) propose as the interactive listening process which enables listeners to interactively employ different aspects of knowledge such as phonology, syntax, semantics, and pragmatics in their effort to decode the meaning of the listening texts.

\section{D.Teachers' shared knowledge of instructional activities in listening lessons}

Exploring the instructional activities that the teachers employed in their listening lessons were the final primary focus in the present study. In the interviews, the teachers were asked to list all the activities they used in each stage of the lessons. In all 9 observed lessons, the researcher also coded each activity based on its purpose. Accordingly, all the activities evident from the teachers' interviews and observed lessons are presented in Table 4 below. As can be seen, the pre-listening stage was dominated by 04 main activities that the teachers focused on including reviewing the previous lessons, setting goals for the new lessons, building background knowledge for the new topic, and pre-teaching vocabulary. Among these, the two most activities consistently employed by all six participants were vocabulary teaching and background knowledge construction that were evident in all 9 observed lessons. It should also be noted that to help students build up background knowledge for the topic, the teachers were found to employ quite different activities such as discussion (lessons 2, 5, 7), story-telling (lesson 9), video watching (lessons 1 \& 8) or simple question-answer speaking activities (lessons 1, 3, 4). In the whilestage, most of the teachers' activities seemed to be mainly constrained by the listening tasks in the prescribed textbooks which mainly included listening for gist and specific details. In this stage, the two added activities in each lesson included a before-listening activity where the teachers asked students to read the questions, analyze keywords and predict the answers before listening and a post-listening task of checking the answers, for which the teachers had a tendency to invite individual students to share their answers and provide explanations for their choice.

\section{TABLE IV}

\section{COMPARISON OF ACTIVITIES THE TEACHERS EMPLOYED IN REPORTED AND ACTUAL CLASSROOM PRACTICES}

\begin{tabular}{|c|c|c|c|}
\hline Lesson stages & Instructional activities & Reported practices & $\begin{array}{c}\text { Actual } \\
\text { Practices }\end{array}$ \\
\hline \multirow{8}{*}{$\begin{array}{c}\text { PRE- } \\
\text { LISTENING }\end{array}$} & Review the previous lesson & $\mathrm{x}$ & $\mathrm{x}$ \\
\hline & Set goals for the new lesson & $\mathrm{x}$ & $\mathrm{x}$ \\
\hline & Build background knowledge & $\mathrm{X}$ & $\mathrm{x}$ \\
\hline & Discussion & $\mathrm{x}$ & $\mathrm{x}$ \\
\hline & Story telling & $\mathrm{x}$ & $\mathrm{x}$ \\
\hline & Questions-answers & $\mathrm{x}$ & $\mathrm{x}$ \\
\hline & Video watching & $\mathrm{x}$ & $\mathrm{x}$ \\
\hline & Pre-teach vocabulary & $\mathrm{x}$ & $\mathrm{x}$ \\
\hline \multirow{5}{*}{$\begin{array}{l}\text { WHILE- } \\
\text { LISTENING }\end{array}$} & Find keywords & $\mathrm{x}$ & $\mathrm{x}$ \\
\hline & Take notes & $\mathrm{x}$ & \\
\hline & Listen for main ideas & $\mathrm{x}$ & $\mathrm{x}$ \\
\hline & Listen for specific ideas & $\mathrm{x}$ & $\mathrm{x}$ \\
\hline & Explain for the answers & $\mathrm{x}$ & $\mathrm{x}$ \\
\hline \multirow{9}{*}{$\begin{array}{c}\text { POST- } \\
\text { LISTENING }\end{array}$} & Sentence building & & $\mathrm{x}$ \\
\hline & Functional language & & $\mathrm{x}$ \\
\hline & Fill in the blank & $\mathrm{x}$ & \\
\hline & Speaking production & & \\
\hline & Summarize & $\mathrm{x}$ & $\mathrm{x}$ \\
\hline & Picture tasks & & $\mathrm{x}$ \\
\hline & Role-play & $\mathrm{x}$ & \\
\hline & Discussion, presentation & $\mathrm{x}$ & $\mathrm{x}$ \\
\hline & Debate & & $\mathrm{x}$ \\
\hline
\end{tabular}

In the post-listening stage, as earlier mentioned, the primary focus in the observed lessons was placed upon speaking production activities. These included summarising (lessons 3 \& 4), discussion in conjunction with presenting ideas in front of the whole class (lessons 1, 4, 6 \& 7), debate (lesson 9), and picture tasks such as describing (lesson 7) or sequencing (lesson 8). Among these production activities, discussion appeared to be the most commonly employed among the teachers. Nonetheless, it should be noted that role-play and further listening practice such as listening and fill in the blanks that the teachers mentioned in the interviews were not 
DOI: $\underline{10.51386 / 25815946 / \mathrm{ijsms}-\mathrm{v} 4 \mathrm{i} 5 \mathrm{p} 102}$

found in their classroom practice. In contrast, in two of the lessons (lessons 2 and 4), the teachers focused more on further providing students with opportunities to refine structural knowledge, either by having students build sentences based on provided words or analyzing and memorizing functional language such as expressions for personal opinions, agreeing and disagreeing. This focus on structural practice in the post-listening stage was not mentioned by any of the teachers in the interviews.

In general, although findings in relation to the instructional activities the teachers employed in their reported and classroom teaching revealed some inconsistency, the majority of main activities they employed across the three lesson stages appeared to be highly consistent among the teachers. Not only did the teachers share the common major goals in each of the lesson stages, they further appeared to have employed quite similar activities that helped them achieve these goals. These teachers' reliance on a similar stock of activities might have been rooted in their alignment with the prescribed textbooks since most of the tasks included in their lessons were readily designed in the materials they were using. An emphasis on the role of prescribed textbooks as the dictatorship of the teaching contents has been reported in a few studies in Vietnamese contexts (Nguyen, 2018; Nam, 2015). Any attempts to change or enrich the teachers' repertoire of instructional activities might need to depart from innovation with the materials prescribed to the teachers, on the other hand, although various studies reported on the mismatches between the teachers' reported and actual classroom practices as a result of contextual factors, the divergence found in the activities employed by the teachers in this study might be due to the limited number of observed lessons. The 9 lessons observed, to some extent, could provide a snapshot of the teachers' classroom practice but by no means they could reveal a comprehensive picture of all that happen in the classrooms. For any conclusive argument to be made on this issue, more long-term research with more comprehensive classroom evidence needs to be conducted

\section{IMPLICATIONS AND CONCLUSION}

This study responded to the scarcity of studies that investigate the teachers' perceptions and practices in teaching the listening skill and limited existing understanding in relation to this topic, especially in the context of Vietnamese tertiary level. Findings from the study, as such, contribute to the expansion in the understanding of listening teaching practice in this particular context and offer a number of important implications for future professional development activities. To begin with, the fact that the teachers in this context were found to mainly see listening as an input source but overlook its role as a macro-language skill or an important learning target suggests that helping teachers obtain a more balanced view of this skill could be seen as a fundamental first step in the attempts to improve the effectiveness in listening instruction in this setting. Secondly, in terms of the contents that the teachers prioritized in teaching, it was found that lexical knowledge, topical background knowledge, and listening strategies functioned as the three most central components in the teachers' reported and classroom practices. Updating teachers with a more comprehensive understanding of all important constituents of the listening subject matter content knowledge, as such, could also be viewed as of crucial importance. As suggested by listening specialists, although lexical and topical knowledge together with listening strategies are well established as core contents in listening teaching and learning, learners need to systematically engage in the listening process and be provided with sufficient opportunities to develop their knowledge of syntax, discourse, semantic, pragmatics together with knowledge cognitive, meta-cognitive and socio-affective strategies in a well-designed and principled fashion (Brown, 1990; Flowerdew \& Miller, 2005; O’Malley \& Chamot, 1990; Vandergift \& Goh, 2012, 2018).

In relation to the teachers' typical lesson structure, evidence indicated the teachers' clear inclination towards a more conventional product-oriented three-stage lesson structure in both reported and actual classroom practices. To a great extent, this reflects a certain level of alignment with the dominant Presentation-Practice-Production lesson pattern that has been reported to be a norm in the Vietnamese context for decades (Bui \& Newton, 2021; Nguyen, 2018, Phuong et al., 2015). It also shows a great extent of resemblance to the product-oriented approach (Vandergrift \& Goh, 2018) to teaching listening. Such a lesson design, however, appears not to be sufficiently and effectively facilitate the desired development of learners' listening ability since it does not comprehensively engage learners in the listening process as well as allow them to develop all knowledge and skills needed for successful listening performance (Brown, 1990; Flowerdew \& Miller, 2005; Vandergrift \& Goh, 2012, 2018). Professional development activities that introduce process-oriented lesson models to teachers and allow them to engage in hands-on experience in lesson planning and delivering lessons to students, as such, will be of ultimate necessity. Furthermore, it was also found that the participants in this study resourced to a 
DOI: $\underline{10.51386 / 25815946 / \mathrm{ijsms}-\mathrm{v} 4 \mathrm{i} 5 \mathrm{p} 102}$

Volume: 4 Issue: 5

September to October 2021

https://www.ijsmsjournal.org

similar group of instructional activities for their listening lessons. This reality, in turn, reflects the fact that the prescribed materials dictate their knowledge and teaching practice to a large extent. In other words, both the teachers' perceptions and practices appeared to be substantially influenced and shaped by the textbooks they used. This further suggests that in efforts to improve the quality of teaching the listening skill in this context, a broad, consistent view on the listening subject matter content and pedagogical approach needs to be clearly reflected in the materials prescribed to the teachers.

Besides these contributions, the present study features a few unavoidable limitations. First, the number of participants was limited to 6 teachers working in the same institution. These findings, as such, need to be interpreted in the context of the researched setting, and transference of these findings to other contexts needs to be done with due caution. In terms of design, the study mainly employed qualitative instruments including interviews and observations. To gain a more comprehensive picture of teachers' perceptions and practice in teaching listening skill, however, the supplement of quantitative evidence obtained from a larger number of teachers across different semesters will provide more powerful insights into the topic under investigation. With triangulated quantitative and qualitative data obtained throughout a long stretch of time, findings and interpretations from the study would be of much greater reliability and value. Also, the observation data were still restricted to each unit per teacher. Although this data set supplies important evidence concerning the teachers' classroom practice with rich information concerning their teaching reality, it only provides a snapshot of the reality, rather than a comprehensive picture. Forthcoming studies focusing on this topic, as such, should be undertaken with a larger size of participants and involve both quantitative and qualitative data. More importantly, such studies need to be carried out in a longer stretch of time so that a more comprehensive picture of the teachers' classroom practice can be fully obtained.

\section{ABOUT THE AUTHORS}

Ly Thanh Danh is an English teacher at the Centre for the Foreign Languages of Can Tho University, Vietnam. He completed a Bachelor's degree in English in Education in 2018. He is currently an MA student at Can Tho University. He is fond of researching speaking and listening skills and strategies, and teaching methodology.

Nguyen Hai Quan is a lecturer at the School of Foreign Languages, Can Tho University, Vietnam. He carries studies on teaching approaches and Intercultural Communicative Competence. He published articles in different journals.

\section{REFERENCES}

[1] Bonk, W. (2000). Second language lexical knowledge and listening comprehension. International Journal of Listening, 14 , 14-31.

[2] Brown, G. (1990). Listening to spoken English. London: Longman.

[3] Brown, S. (2006). Teaching Listening. New York: Cambridge University Press.

[4] Buck, G. (2001). Assessing listening. Cambridge, UK: University Press.

[5] Burgo, C. (2015). Grammar Teaching Approaches For Heritage Learners Of Spanish. Learn Language, Explore Cultures, Transform Lives (Report of the Central States Conference on the Teaching of Foreign Languages), 217-233.

[6] Çakir, I. (2006). The use of video as an audio-visual in foreign language classroom. The Turkish Online Journal of Educational Technology, 5(4),2-3.

[7] Canh, L.V., \& Barnard, R. (2009). Curricular innovation behind closed classroom doors: A Vietnam case study. Prospect, 24 (2), 2033.

[8] Corbin, J., \& Strauss, A. L. (2008). Basics of Qualitative Research (3rd Edition). Thousand Oaks: SAGE Publications, Inc.

[9] Cross, J., (2011). Metacognitive instruction for helping less-skilled listeners. English Language Teaching Journal, 65(4), 408-416.

[10] Dao, T. K. N. (2013). Students' English listening anxiety: Causes and solutions (Unpublished master's thesis), Vietnam National University, Hanoi, Vietnam. Retrieved from http://123doc.org/timkiem/research+about+learning+listening+skill.htm. 


\section{DOI: $\underline{10.51386 / 25815946 / \mathrm{ijsms}-\mathrm{v} 4 \mathrm{i} 5 \mathrm{p} 102}$}

[11] Duong, T. M., \& Chau, N. T. (2019). English listening comprehension problems perceived by English majors. In T. T. Dang (Eds.), Proceedings of International Conference on Language Teaching and Learning Today 2019: Autonomy and Motivation for Language Learning in the Interconnected World (pp. 209-222). Ho Chi Minh City: Vietnam National University-Ho Chi Minh City Press.

[12] Field, J (1998). Skills and strategies: towards a new methodology for listening, ELT Journal 52 (2), 110-118.

[13] Field, J. (2004). An insight into listeners' problems: Too much bottom-up or too much top-down? System, 32, $363-77$. doi:10.1016/j.system.2004.05.002

[14] Field, J. (2008). Listening in the Language Classroom. Cambridge: Cambridge University Press.

[15] Field, J. (2012). Listening instruction. The Cambridge guide to pedagogy and practice in second language teaching (pp. 207-217). New York: Cambridge University Press.

[16] Flowerdew, J. \& Miller, L. (2005). Second Language Listening: Theory and Practice. (22-23) Cambridge University Press, USA.

[17] Goh, C. (2008). Metacognitive instruction for second language listening development: Theory, practice and research implications. RELC Journal, 39,188-213.

[18] Goh, C. (2010). Listening as process: learning activities for self-appraisal and self-regulation. In N. Harwood (Ed.), English language teaching materials: Theory and practice (pp. 179e206). Cambridge: Cambridge University Press.

[19] Graham, S. (2006). Listening comprehension: The learners' perspective. System, $34 \quad$ (2), 165- 182. http://dx.doi.org/10.1016/j.system.2005.11.001

[20] Graham, S., Santos, D., \& Francis-Brophy, E. (2014). Teacher beliefs about listening in a foreign language. Teaching and Teacher Education, 40, 44-60. doi:10.1016/j.tate.2014.01.007

[21] Graham, S., Santos, D., \& Vanderplank, R. (2011). Exploring the relationship between listening development and strategy use. Language Teaching Research, 15(4), 435-456. doi: $10.1177 / 1362168811412026$

[22] Harmer, J (2001), The Practice of English Language Teaching 3rd Edition, Longman Press, Pearson Education ESL, NJ, US.

[23] Hinkel, E. (2006). Current perspectives on teaching the four skills. TESOL Quarterly, 40 (1), 109-131.

[24] Holden, R. W. (2004). Facilitating listening comprehension: Acquiring successful strategies. Bulletin of Hokuriku University, 28, $257-266$.

[25] Luu, Q. K., \& Phung, N. Q. N. (2013). A study of difficulties faced by EFL teachers in teaching listening at high schools in Nghe An province: A case study with currrently used textbook “Tieng Anh 11". Tạp Chí Khoa Học và Công Ngh ệ (Sciences and Technology Journal), 63(2), 64-70.

[26] Marianne, Donna and Janet (1996). Teaching Pronunciation, Cambridge University Press.

[27] Maynard, T. (2002). Boys and literacy: Exploring the issues. London: Routledge.

[28] Mecartty, F. H. (2000). Lexical and grammatical knowledge in reading and listening comprehension by foreign language learners of Spanish. Applied Language Learning, 11(2), 323-348.

[29] Miller, J. (2005), 'Most of ESL students have trouble with the articles', International Education Journal, ERC2004 Special Issue, vol. 5 , no. 5 , pp. $80-88$

[30] Nam, T. G. (2015). Investigating teachers' implementation of the task-based curriculum from a teacher cognition perspective: A case study of a Vietnamese upper-secondary school. (Unpublished doctoral dissertation), University of Wollongong.

[31] Nation, I. S. P. \& Webb, S. (2011). Researching and analysing vocabulary. Boston: Heinle Cengage Learning.

[32] Newton, J. M., \& Nation, I. S. P (2020). Teaching Esl/Efl Listening and Speaking. (2nd Ed.) (New York: Routledge.

[33] Nguyen, V. G. (2014). Forms or meaning? Teachers' beliefs and practices regarding task-based language teaching: A Vietnamese case study. The Journal of Asia TEFL, 11(1), 1-36.

[34] Nguyen, H. Q. (2018). Speaking pedagogy: Insights from Vietnamese EFL teachers' cognitions and classroom practice. (Unpublished doctoral dissertation), University of Wollongong. 


\section{DOI: $\underline{10.51386 / 25815946 / \mathrm{ijsms}-\mathrm{v} 4 \mathrm{i} 5 \mathrm{p} 102}$}

[35] Nguyen, Q. N., \& Thai, D. C. (2018). Listening comprehension: First-year English-major students' perceptions and problems. Can Tho University Journal of Science, 54 (2), 75- 83.

[36] Nunan, D. (1997). Listening in Language Learning. JALT Journal of the Language Teacher, 9(15), 1-5. http://jaltpublications.org/tlt/files/97/sep/nunan.html.

[37] Nunan, D. (1998). Approaches to teaching listening in language classroom. In proceedings of the 1997 Korean TESOL Conference. Taejon, Korea: KOTESOL.

[38] Ockey, G. J. (2007). Construct implications of including still image or video in computer-based listening tests. Language Testing, 24 (4), 517-537.

[39] O’Malley, J.M., \& Chamot, A. U. (1990). Learning strategies in Second Language Acquisition. Cambridge: Cambridge University Press.

[40] Patton, M. Q. (1990). Qualitative evaluation and research methods (2nd ed.). Newbury Park, CA: Sage.

[41] Richards, J. C. (2005). Second thoughts on teaching listening. RELC Journal, 36 (1), 85- 92.

[42] Ridgway T (2000). Listening strategies- I beg your pardon? ELT Journal, 54, 179- 185.

[43] River \& Temperley M. S. (1978). A practical guide to the teaching of English as a Second or Foreign Language. New York: Oxford University Press.

[44] Rivers, W. M., \& Nunan, D. (1991). Language teaching methodology: A textbook for teachers. Hertfordshire: Prentice Hall International.

[45] Rost, M. (1994). Introducing Listening. London: Penguin books.

[46] Rost, M. (2001). Listening. In R. Carter, \& D. Nunan (Eds.), The Cambridge Guide to Teaching English to Speakers of Other Languages (pp. 7-13). Cambridge: Cambridge University Press. http://dx.doi.org/10.1017/CBO9780511667206.002

[47] Rubin, J. (1995). An overview to a guide for the teaching of second language listening. In D. J. Mendelsohn \& J. Rubin (Eds.), A guide for the teaching of second language listening. San Diego, CA: Dominie Press, Inc.

[48] Rumelhart, D. E. (1975). Notes on a schema for stories. In D. G. Bobrow, \& A. Collins (Eds.), Representation and understanding: Studies in cognitive science (pp. 211-236). New York: Academic Press.

[49] Rumelhart, D. E. (1980). Schemata: The building blocks of cognition. In Spiro, R. J., Bruce, B. C., and Brewer, W. F. (eds.) Theoretical issues in reading comprehension. Hillsdale NJ: L. Erlbaum. 3-58.

[50] Siegel, J. (2013). Second language learners' perceptions of listening strategy instruction. Innovation in Language Learning and Teaching, 7(1), 1-18.

[51] Thai, C. D., \& Nguyen, N. Q. (2018). Listening comprehension: First year English-major students' perceptions and problems. Can Tho University Journal of Science, 54(2), 75-83. https://doi.org/10.22144/ctu.jen.2018.010

[52] Titsworth, B. S. \& Kiewra, K. A. (2004). Spoken organizational lecture cues and student note-taking as facilitators of student learning. Contemporary Educational Psychology, 29 (4), 447-61.

[53] Vandergrift L. (1999) Facilitating second language listening comprehension: acquiring successful strategies. ELT journal 53(3), pp.168-176.

[54] Vandergrift, L. (2003). Orchestrating strategy use: Towards a model of the skilled L2 listener. Language Learning, 53, 461-494.

[55] Vandergrift, L. (2007). Recent developments in second and foreign language listening comprehension research. Language Teaching, $40,191-210$.

[56] Vandergrift, L. (2011). Second language listening: presage, process and pedagogy. In: E. HINKEL, ed. Handbook of research in second language teaching and learning. Volume II. New York: Routledge. 455-471.

[57] Vandergrift, L., \& Baker, S. (2015). Learner variables in second language listening comprehension: An exploratory path analysis. Language Learning, 65, 390-416. 
DOI: $\underline{10.51386 / 25815946 / \mathrm{ijsms}-\mathrm{v} 4 \mathrm{i} 5 \mathrm{p} 102}$

Volume: 4 Issue: 5

[58] Vandergrift, L. \& Goh, C. (2018). Introduction to listening. In J. M. Newton, D. R. Ferris, C. C. M. Goh, W. Grabe, F. L. Stoller, \& L. Vandergrift (Eds.), Teaching English to second language learners in academic contexts (pp. 123-144). Devon, United Kingdom, Routledge.

[59] Van den Branden, K. (2006). Task-based language teaching: from theory to practice. Cambridge: Cambridge University Press.

[60] Vogely, A. (1999). Addressing listening comprehension anxiety. Affect in foreign language and second language learning: A practical guide to creating a low-anxiety classroom atmosphere. New York, New York: McGraw-Hill.

[61] Vo. T. N. H. (2014). An investigation into listening instruction and application in a private EFL school in Vietnam. (Unpublished Master Thesis). Ha Noi University of Languages and International Studies.

[62] Wilson, JJ. (2008). How to Teach Listening. Essex: Pearson Education Limit.

[63] Wilson, M. (2016). The ethical foundation of analytic action. Journal of the American Psychoanalytic Association, 64, 1189-1205. 